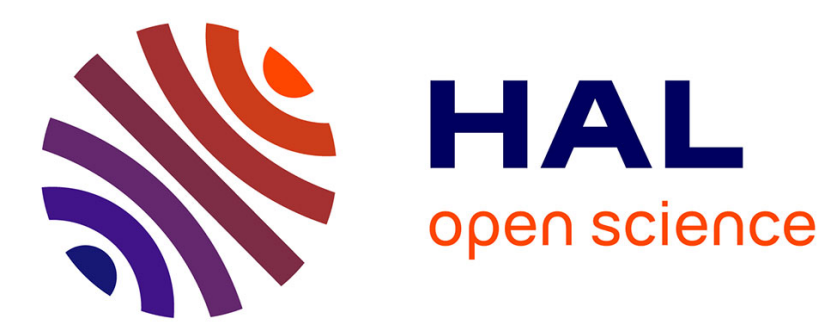

\title{
The changing role of learning regions in the globalising knowledge economy: A theoretical re-examination
}

Bjorn Asheim

\section{To cite this version:}

Bjorn Asheim. The changing role of learning regions in the globalising knowledge economy: A theoretical re-examination. Regional Studies, 2011, pp.1. 10.1080/00343404.2011.607805 . hal-00746199

\author{
HAL Id: hal-00746199 \\ https://hal.science/hal-00746199
}

Submitted on 28 Oct 2012

HAL is a multi-disciplinary open access archive for the deposit and dissemination of scientific research documents, whether they are published or not. The documents may come from teaching and research institutions in France or abroad, or from public or private research centers.
L'archive ouverte pluridisciplinaire HAL, est destinée au dépôt et à la diffusion de documents scientifiques de niveau recherche, publiés ou non, émanant des établissements d'enseignement et de recherche français ou étrangers, des laboratoires publics ou privés. 


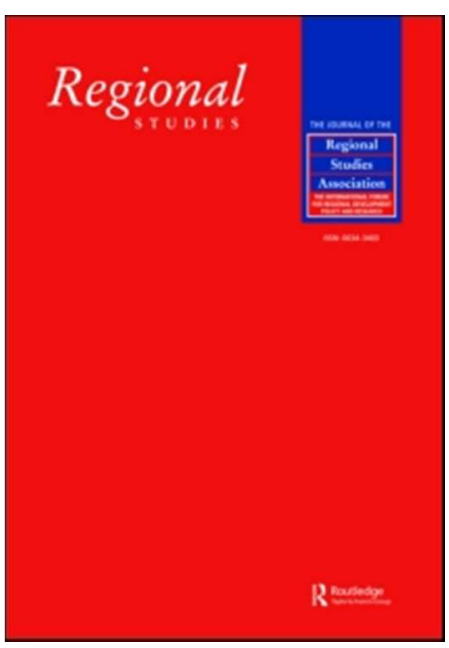

\section{The changing role of learning regions in the globalising knowledge economy: A theoretical re-examination}

\begin{tabular}{|r|l|}
\hline Journal: & Regional Studies \\
\hline Manuscript ID: & CRES-2009-0349.R2 \\
\hline Manuscript Type: & Main Section \\
\hline JEL codes: & $\begin{array}{l}\text { O18 - Regional, Urban, and Rural Analyses < O1 - Economic } \\
\text { Development < O - Economic Development, Technological Change, and } \\
\text { Growth, O2 - Development Planning and Policy < O - Economic } \\
\text { Development, Technological Change, and Growth, O30 - General < O3 - } \\
\text { Technological Change|Research and Development < O - Economic } \\
\text { Development, Technological Change, and Growth, R1 - General Regional } \\
\text { Economics < R - Urban, Rural, and Regional Economics }\end{array}$ \\
\hline Keywords: & the learning region, learning, knowledge, innovation, innovation policy \\
\hline \multicolumn{2}{|c}{} \\
\hline
\end{tabular}

\section{SCHOLARONE ${ }^{m}$}

Manuscripts 


\title{
The Changing Role of Learning Regions in the Globalising Knowledge Economy: A Theoretical Re-examination
}

\author{
BJØRN ASHEIM \\ Centre for Innovation, Research and Competence in the \\ Learning Economy (CIRCLE)/Department of Human Geography, \\ Lund University, Sweden; and University of Agder, Norway. \\ P.O. Box 117, SE-22100 Lund, Sweden. Email: Bjorn.Asheim@circle.lu.se
}

(Received November 2009: in revised form June 2011) 


\begin{abstract}
Highlighting four theoretical developments, this paper theoretically re-examines the Learning Region in view of the changing roles of regions in the globalising knowledge economy. 1) From specific contexts to general regional development strategies, 2) Introducing the Doing Using Interacting-mode of innovation, 3) Broadening the Science Technology and Innovation-mode, and 4) Accessing knowledge in distributed knowledge networks. The paper advocates a more nuanced understanding of knowledge, learning and innovation and identifies 'bridging mechanisms' to reduce cognitive distance and increase connectivity in regional innovation systems.
\end{abstract}

Keywords: Learning regions, Knowledge bases, Modes of innovation, Knowledge economy, Developmental learning, Globalisation

JEL: O 18, O 31, O 34, R 11

\title{
INTRODUCTION: WHAT IS A "LEARNING REGION"?
}

In a recent book (RUTTEN and BOEKEMA, 2007) four articles are reprinted as representing the foundations of the concept of learning regions: STORPER, 1993; FLORIDA, 1995; ASHEIM, 1996; and, finally, MORGAN, 1997. This demonstrates that the concept of 'learning regions' is a product of the 1990s and reflects empirically the rapid economic development in places such as the "Third Italy", which drew the attention towards the importance of co-operation between SMEs in industrial districts and between firms and local authorities at the regional level in achieving international competitiveness 
(ASHEIM, 2000). Theoretically, it reflects the definition of post-Fordist societies as learning economies, where innovation is seen as basically a socially and territorially embedded, interactive learning process, which cannot be understood independent of its institutional and cultural contexts (LUNDVALL and JOHNSON, 1994).

Even if these contributions in many ways have a common view on how to understand 'learning regions', underlining the important role of innovation, understood as contextualised social processes of interactive learning, they also disclose interesting differences. One such difference can be identified between the American and European approaches (RUTTEN and BOEKEMA, 2007). While learning regions in a North American context are associated with the importance of the quality of the knowledge infrastructure of leading universities and research institutions in a knowledge-based, high-tech economy, producing, attracting and retaining highly skilled workers (e.g. Silicon Valley) (FLORIDA, 1995), in a European context of learning economies the focus is much more on the role social capital and trust plays in promoting formal and informal inter-firm networks and the process of interactive learning (e.g. industrial districts in the Third Italy) (ASHEIM, 1996; MORGAN, 1997). The broadness in the different interpretations of learning regions clearly also demonstrates that the concept can be fuzzy and the use of the concept both theoretically and practically rather flexible.

At least one could say that the concept of "learning regions" has been used in three different ways (ASHEIM, 2001). The concept was originally introduced by economic geographers in the mid 1990s, when they used it to emphasise the role played by co- 
operation and collective learning in regional clusters and networks in order to promote the innovativeness and competitiveness of firms and regions (ASHEIM, 1996; MORGAN, 1997). The second approach expressing the idea of learning regions originates from the writings of evolutionary and institutional economics on the learning economy, where innovation is seen as basically a socially and territorially embedded, interactive learning process, making knowledge the most fundamental resource and learning the most important process (LUNDVALL and JOHNSON, 1994). The third approach, which conceptualises learning regions as regionally based development coalitions, has been developed by action oriented organisational researchers taking their knowledge of how to form intra- and inter-firm learning organisations based on broad participation out of the firm context and applying it at the regional level as a bottom-up, horizontally based co-operation between different actors in a local or regional setting (ENNALS and GUSTAVSEN, 1999).

\begin{abstract}
According to this third perspective learning regions should be looked upon as a strategy for formulation of long term partnership-based development strategies initiating learningbased processes of innovation and change. In the promotion of such learning regions the inter-linking of learning organisations ranging from work organisations inside firms via inter-firm networks to different actors of the community, understood as "regional development coalitions" (ENNALS and GUSTAVSEN, 1999), is highlighted. Of strategic importance in this context is the capacity of people, organizations, networks and regions to learn (LUNDVALL, 2008). The concept of a learning region can, thus, be used to describe a region characterised by innovative activity based on localised, interactive
\end{abstract}


learning, and co-operation promoted by organisational innovations in order to exploit learning based competitiveness (AMIN and THRIFT, 1995).

Planners and politicians find the concept of learning regions attractive as it at one and the same time promises economic growth and job generation as well as social cohesion. As such, learning regions may be analysed as an answer and challenge at the regional level especially for regions with weak territorial competence bases to contemporary changes in the global economy, underlining the strategic role played by social capital's emphasis on the social and cultural aspects of regions facilitating collective action for mutual benefit (WOOLCOCK, 1998). Thus, it is not accidental that this approach to learning regions was used by the Regional Innovation Strategies pilot actions of the EU Commission as part of new policy developments in Europe since the 1990s to promote less developed regional economies within EU through innovation (BELLINI and LANDABASO, 2007).

\section{THEORETICAL DEVELOPMENTS I: LEARNING ECONOMY AND DEVELOPMENT COALITIONS}

The second and the third approaches referred to above implied new theoretical perspectives in relation to the first approach as represented by economic geographers and building on the work mainly of Italian heterodox economists' studies of industrial districts of the Third Italy. The learning economy input gave a theoretical substantiation of the importance of socio-cultural and institutional structures in regional development, highlighting the significance of building social capital in order to foster co-operation. This meant that such structures should no longer be viewed as vestigial remnants of pre- 
capitalist civil societies as often was the case in studies of traditional industrial districts, but rather be looked upon as necessary prerequisites for firms and regions to be innovative and competitive in a post-Fordist learning economy. The theoretical underpinnings of this are the understanding of interactive learning as a fundamental aspect of the process of innovation, which points to the strategic role played by cooperation in a learning region. This represented a new perspective of the sustainability of the Third Italy type of learning regions as being able to compete and survive even in a globalising economy.

When learning regions are defined as regional development coalitions they resemble a regional innovation system broadly defined, which includes the wider setting of organisations and institutions affecting and supporting learning and innovation in a region with an explicit focus on competence building and organisational innovations (ASHEIM and GERTLER, 2005; LUNDVALL, 1992, 2008). This type of system is less systemic with respect to university-industry relations than the narrowly defined types of innovation systems. Firms mainly base their innovation activity on interactive, localised learning processes stimulated by geographical, social and cultural/institutional proximity, without much direct contact with knowledge creating organisations (i.e. R\&D institutes and universities) (ASHEIM and GERTLER, 2005). Due to its broadness it can, however, play a very important role in establishing a 'culture of innovation' in a region, and, thus, reach out to more 'normal' people than the other type of innovation systems. Key aspects of this perspective are that it emphasizes the importance of partly embedding the innovation process at the work place (micro) level, and partly the dynamic interplay 
between the micro, meso and macro levels, where "macro-structures condition microdynamics and vice versa new macro-structures are shaped by micro-processes" (LUNDVALL, 2008, 101). A narrow definition of innovation systems on the other hand primarily incorporates the $\mathrm{R} \& \mathrm{D}$ functions of universities, public and private research institutes and corporations.

The importance of defining learning regions as regional development coalitions resembling a broadly defined regional innovation system lies in the linking up with the innovation system approach. This expands the political usefulness of the learning regions approach, which is underlined by the use of it in the Regional Innovation Strategies pilot actions of the EU Commission mentioned above.

Knowledge and innovation should, thus, not simply be equated with R\&D. Innovative activities have much broader knowledge bases than just science based $R \& D$, and there are many examples of nations and regions demonstrating a rapid economic growth and a high level of living standard with an industry competing on the bases of non-R\&D based, incremental innovations (e.g. Denmark and regions in The Third Italy). Thus, a region's knowledge base is larger than its science base, implying that arguing for an increasingly more knowledge intensive globalising economy does not necessarily mean that innovation and competitiveness becomes more dependent on R\&D.

\section{THEORETICAL DEVELOPMENTS II: DUI MODE OF INNOVATION AND DEVELOPMENTAL LEARNING}


The distinction between non-R\&D and R\&D based (regional) economies implies the use of different modes of innovation (LORENZ and LUNDVALL, 2006). On the one hand we can talk about a broad definition of the mode of innovation as $\mathrm{D}$ (oing), U(sing) and I(nteracting) relying on informal processes of learning and experience-based know-how. The DUI (Doing, Using, Interacting) mode is a user ormarket driven model based more on competence building and organizational innovations and producing mostly incremental innovations. Such a mode of innovation is typically found in non-R\&D based economies (e.g. Denmark). On the other hand one finds a more narrow definition of the mode of innovation as S(cience), T(echnology) and I(nnovation) based on the use of codified scientific knowledge, which is a science push/supply driven high tech strategy able to produce radical innovations. These two modes of innovation will also be differently manifested with regard to regional specialisation and clustering. The narrowly defined innovation system correspond to the STI mode of innovation mentioned above, while the more broadly defined system is more easily accommodated by the DUI mode of innovation.

The distinction between these two modes of innovation helps on the one hand to avoid a too one-sided focus on promoting science-based innovation of high-technology firms at the expense of the role of learning and experience-based, user-driven innovation. On the other hand it also indicates limits of such innovation strategies and, thus, emphasizes the need for firms in traditional manufacturing sectors and services more generally to link up with sources of codified knowledge in distributed knowledge networks (BERG JENSEN et al., 2007). SMEs, for example, may have to supplement their informal knowledge, 
characterized by a high tacit component (i.e. the DUI mode of innovation), with competence arising from more systematic research and development (i.e. the STI mode of innovation) in order to carry out more radical innovations. In the long run, most firms cannot rely exclusively on informal localised learning, but must also gain access to wider pools of both scientific (analytical) and engineering (synthetic) knowledge (see next section) on a national and global scale (ASHEIM et al., 2003).

Empirically this is clearly demonstrated by the changes that traditional IDs of the Third Italy have undergone as a consequence of globalization. From being nearly almost regionally endogenous contained (e.g. the whole value chain used to be within the district), increased outsourcing/offshoring, dependence on international knowledge flows through FDIs and TNCs acquiring local industry, inflow of foreign workers (both legal and illegal), and more formal networks between local firms through group formation have 'modified' industrial districts into becoming 'ordinary' clusters. These changes have had obvious impacts on the traditional, more informal forms of interactive learning within the local value chain of client firms, suppliers and subcontractors that dominated the picture before, which was based on 'the fusion of economy and society' (PIORE and SABEL, 1984) or the 'socio-economic notion' of the districts (BECATTINI, 1990), with implications also for the sustainability of the learning regions' idea in its original version. Thus, integration into more globally distributed knowledge networks and value chains could represent one solution to the problems of 'lock-in' due to lack of innovative capacity, which eventually would place such districts in a low road, cost squeezing form of competition. Another solution would be the already mentioned option of combining 
the dominating DUI mode of innovation of the traditional districts firms with the STI mode. New research confirms that combining the two modes of innovation seems to be most efficient, i.e. firms that have used the STI-mode intensively may benefit from paying more attention to the DUI-mode and vice versa (BERG JENSEN et al., 2007; LORENZ and LUNDVALL, 2006). In this way, on the firm levels these two modes of innovation can (and should) co-exist, but they will be applied in different combinations depending on the dominating knowledge base(s).

However, even staying within a DUI mode of innovation gives more innovative possibilities than previously recognised. This position is linked to research challenging the traditional view of learning as only incremental (or reproductive/adaptive) (COOKE, 2007). ELLSTRÖM, 1997 emphasizes that learning is not only reproductive or adaptive (resulting in imitation) but that it also can be developmental and creative. Ellström uses these categories to make a distinction between developmental learning which he sees as the 'logic' of knowledge exploration on the one hand, and reproductive or adaptive learning which represents the 'logic' of knowledge exploitation in his view. New research on the relationship between forms of work organisation in EU and the impact on job stress, worker satisfaction, labour market flexibility, learning, innovation and patenting confirms that learning also can be developmental and creative due to the high degree of work autonomy and learning dynamics found in learning forms of work organisation. This study distinguishes between four main forms of work organisation: 'learning', 'lean', 'Taylorist' and 'simple structure'. It shows that not only does the learning work organization result in less job stress and greater worker satisfaction, it also 
implies more labour market flexibility, superior conditions for learning and innovation, and even a larger propensity for patenting (ARUNDEL et al., 2007; LORENZ and VALEYRE, 2006). The study shows a clear north-south divide with regard to the dominating forms of work organization with Northern Europe dominated by learning forms of work organization, while Southern Europe has work organizations characterized by either Taylorist or simple forms. The positive impact of the learning form of work organization on innovation is confirmed by another study reporting that 'low road' practices using short-term and temporary contracts, having a lack of employer commitment to job security, low levels of training, and so on are negatively correlated with innovation. In contrast, it is found that 'high road' work practices characterized by 'high commitment' organisations or 'transformed' workplaces are positively correlated with innovation (MICHIE and SHEEHAN, 2003). This implies that a DUI mode of innovation which has learning work organizations as its micro foundation in addition to the interactive from of innovation on the meso level not only should be expected to produce incremental innovation but also has the potential of creating radical innovations due to the presence of developmental learning. Thus, such an 'upgraded' DUI mode of innovation could well establish itself as a 'high road' strategy in the globalizing knowledge economy. However, this possibility would clearly be strengthened through combining the DUI mode of innovation with the STI mode.

\section{THEORETICAL DEVELOPMENTS III: STI MODE OF INNOVATION AND}

\section{DIFFERENTIATED KNOWLEDGE BASES}

When one considers the actual knowledge bases and competences of various industries 
and sectors of the economy, it is clear that knowledge creation and innovation processes have become increasingly complex, diverse and interdependent in recent years. There is a larger variety of knowledge sources and inputs to be used by organisations and firms, and there is more collaboration and division of labour among actors (individuals, companies, and other organisations). However, the binary argument of whether knowledge is codified or tacit can be criticized for a restrictively narrow understanding of knowledge, learning and innovation (JOHNSON et al., 2002). Thus, a need to go beyond this simple dichotomy can be identified. One way of doing this is to study the basic types of knowledge used as input in knowledge creation and innovation processes. By way of suggesting an alternative conceptualization, a distinction can be made between 'synthetic', 'analytical', and 'symbolic' types of knowledge bases.

Following received wisdom from the philosophy of science, an epistemological distinction can be identified between two more or less independent and parallel forms of knowledge creation, 'natural science' and 'engineering science' (LAESTADIUS, 2000). JOHNSON et al., 2002, p. 250 refer to the Aristotelian distinction between on the one hand 'epistèmè: knowledge that is universal and theoretical', and 'technè: knowledge that is instrumental, context specific and practice related'. The former corresponds with the rationale for 'analysis' referring to understanding and explaining features of the (natural) world (natural science/know-why), and the latter with 'synthesis' (or integrative knowledge creation) referring to designing or constructing something to attain functional goals (engineering science/know-how) (SIMON, 1969). A main rationale of activities drawing on symbolic knowledge is creation of alternative realities and expression of 
cultural meaning by provoking reactions in the minds of consumers through transmission in an affecting, sensuous medium (table 1):

--- Please insert table 1 here ---

The distinction between the knowledge bases takes specific account of the rationale of knowledge creation, the way knowledge is developed and used, the criteria for successful outcomes, and the strategies of turning knowledge into innovation to promote competitiveness, as well as the interplay between actors in the processes of creating, transmitting and absorbing knowledge. The knowledge bases contain different mixes of tacit and codified knowledge, codification possibilities and limits, qualifications and skills required by organisations and institutions involved as well as specific innovation challenges and pressures, which in turn help explaining their different sensitivity to geographical distance and, accordingly, the importance of spatial proximity for knowledge creation. Thus, the dominance of one mode arguably has different spatial implications for the knowledge interplay between actors than another mode of knowledge creation. Analytical knowledge creation tends to be less sensitive to distance-decay 
facilitating global knowledge networks as well as dense local collaboration. Synthetic and symbolic knowledge creation, on the other hand, has a tendency to be relatively more sensitive to proximity effects between the actors involved, thus favouring local collaboration (MOODYSSON et al., 2008).

The underlying idea behind the differentiated knowledge base approach is not to explain the level of competence (e.g. human capital) ${ }^{\mathrm{i}}$ or the R\&D intensity (e.g. high tech or low tech) of firms but to characterise the nature of the basic (or critical) knowledge input which knowledge creation and innovation processes cannot do without. Thus, knowledge bases should be understood as ontological, generic categories, and, consequently, most concrete activities are in practice comprised of more than one knowledge base. The degree to which certain knowledge bases dominate, however, varies and is contingent on the characteristics of the firms and industries as well as between different type of activities (e.g. research and production). According to LAESTADIUS (2007) this approach also implies that no type of knowledge should a priory be classified as more advanced, complex, and sophisticated than other knowledge, or to consider science based (analytical) knowledge as more important for innovation and competitiveness of firms, industries and regions than engineering based (synthetic) knowledge or artistic based (symbolic) knowledge. This is once more a question of contingency with respect to the firm, industries, and regions in focus, which among other factors is determined by the path dependency of the traditional technological trajectories and their capacity of creating positive lock-in, upgrading existing industries (i.e. changing technological trajectories) and/or promoting new emerging industries. 
Referring to BERG JENSEN et al., 2007 and LORENZ and LUNDVALL, 2006 the 'Science, Technology and Innovation' (STI) mode of innovation, based on the use of codified scientific knowledge, could broadly be associated with the analytical knowledge base, while the 'Doing, Using and Interacting' (DUI) mode, relying on informal processes of learning and competence building and experience-based know-how, would mostly resemble the synthetic and symbolic knowledge bases. However, once again we shall argue that such a dichotomy becomes too crude especially when discussing the possible combination of the two modes of innovation.

The DUI mode of innovation is characterized by its focus on experience-based knowledge and the recombination of knowledge from various internal and external sources. Thus, it involves numerous actor groups in flexible forms of organisations and networks, and generates knowledge which may be highly tacit and specialized with respect to its context of development and application due to path dependency. The STI mode of innovation, on the other hand, is characterized by its emphasis on structured search, selection and application, in which external-to-firms interpretative frameworks and processes dominate. In combining these to modes, the issues of cognitive distance, organisational forms and absorptive capacity becomes crucial (NOOTEBOOM, 2000; van den BOSCH et al., 1999; KOGUT and ZANDER, 1996; COHEN and LEVENTHAL, 1990). ${ }^{\text {ii }}$

The process of absorbing ideas and knowledge can be conceptualised as involving several 
stages of interfacing and social processing, which are tightly interwoven with organisational forms. External knowledge must be identified within the search spaces of organisations and acquired through interface mechanisms suited for the purpose. This can be referred to as the system dimension of absorptive capacity and knowledge recombination; i.e. how external networks in various forms create linkages, focuses attention and, thus, expose organisations to external knowledge in various forms.

External knowledge must also be evaluated based on pre-existing cognitive frameworks, transformed through recombinations with existing internal knowledge and exploited through processes of innovation and production (ZAHRA and GEORGE, 2002). This cognitive, intra-organizational dimension of absorptive capacity is equally relevant at both the firm and research system parts of a RIS. The dynamic capabilities of an evolving absorptive capacity are highly influenced by the history of practice at the organisational and regional levels respectively, which differs across the DUI and STI dimensions. From this follows that if the cognitive distances and the differences in processes of knowledge acquisition, assimilation and transformation between the two modes of innovation are perceived by key actors to be too wide, it will not be possible to combine them and to view them as complementary instead of incompatible alternatives as well as to appreciate the potential gains of the other mode of innovation.

There are, however, two 'bridging mechanism' which could assist in achieving complementarity between the two modes. The first of these is to understand that the STI mode is not only limited to an analytical knowledge base, but must also include synthetic 
and symbolic knowledge bases, and that the DUI mode is not limited to industries based on synthetic or symbolic knowledge as also dominantly analytical based industries (e.g. pharmaceutical and biotech industries) make use of synthetic knowledge in specific phases of their innovation processes (EBENSBERGER and HERSTAD, forthcoming; HERSTAD et al., 2008; LAURSEN and SALTER, 2004; MOODYSSON, COENEN and ASHEIM, 2008). In the case of synthetic knowledge and STI this can be illustrated by reference to applied research undertaken at (technical) universities, which clearly must be part of the STI mode, but mainly operates on the basis of synthetic (engineering) knowledge, while the case of symbolic knowledge can partly be substantiated by the new tendency of changing design education from being artisan based to be placed at universities with research based teaching, and partly by the steadily increasing research in game soft ware and new media, which in some countries, e.g. in Denmark, is located at new, specialized universities (e.g. the IT university in Copenhagen). This broadening of what constitute the STI mode of innovation shows that also activities based on synthetic and symbolic knowledge bases need to undertake new knowledge creation and innovation in accordance with a STI mode, and, thus, needs systemic relations with universities or other types of $\mathrm{R} \& \mathrm{D}$ institutes (e.g. in a regional innovation system context).

The second 'bridging mechanism' relates to the role of internal organisational processes defining the absorptive capacity of individual firm or research organisations, and, thus, their individual contribution to the absorptive and recombinative capacity of the region as a whole. Keeping in mind the differences between non-structured processes of innovation 
search (sensing, gathering information and ideas), planned processes of innovation sourcing (outsourcing of R\&D), and collaboration (committed two-way exchanges of knowledge) (FEY and BIRKENSHAW, 2005), one may argue that different parts of an organisation support interfacing along different dimensions (search, sourcing, collaboration), towards different actor groups (e.g. customers or universities) or different disciplines (i.e. biotechnology or chemistry). Different employees represent different competencies and cognitive interpretative frameworks, and come with their own individual personal networks. They work in different parts of the organisation, and are consequently exposed to signals from different parts of the external environment (ROTHERMAEL et al., 2006; JACOBIDES and BILLINGER, 2006). However, as COHEN and LEVINTHAL (1990) pointed out, the initial point of entry of knowledge and ideas (e.g. acquisition by a research division) is not necessarily the right point of assimilation, recombination, transformation and exploitation. This means that while the absorptive capacity of subunits or individuals may be high, the absorptive and recombinative capacity at the level of the organisation may still be low if it does not manage to make ideas and knowledge available to relevant users internally. This points towards the importance of a deep and broad internal diffusion of ideas and knowledge, which means that internal cross-functional and hierarchical integration of work processes becomes a critical prerequisite for absorptive capacity.

The innovative potential that a learning work organisation can display in being the operative context for developmental learning is of key importance in this connection (ELLSTRÖM, 1997; LORENZ and LUNDVALL, 2006, KOGUT and ZANDER, 1996). 
Even the most analytical, science based company will obviously benefit from having a work organisation where learning dynamics is created by giving their employees autonomy in their work. This has to build on the principles of broad participation of functional, flexible workers in accordance with the Nordic model of a learning work organization (ENNALS and GUSTAVSEN, 1999).

These lines of reasoning point to critical issues of both the firm and public research organisation subsectors of a RIS, and consequently to the system as a whole. A broad based innovation policy needs both narrow and broad defined innovation systems to be implemented in order to promote the ability of its knowledge diffusion infrastructure to link actor groups which individually are placed at different points on the DUI - STI continuum into processes of innovative recombination and co-evolution. These actors represent different but potentially related internal knowledge development processes, and different but potentially complementary extra-regional networks.

In order to illustrate the importance of these 'bridging' mechanisms we shall give a concrete example taken from a large, international company that is world leading within its area. This is an engineering company whose products are based on a synthetic knowledge base with all the typical characteristics of this knowledge base: problemsolving and custom production based on interactive learning with customers and suppliers. Knowledge is partly codified with a strong tacit component, and is clearly context-specific. Core competence of the company is to comprehend the complex construction process of the equipment in a holistic way. The point is not to understand the 
individual 'machines' being needed, but to understand the individual machines as part of a system. This is a very complicated process with more than 1.000 different steps, which clearly underlines the problem-solving and custom oriented manufacturing process of a typical synthetic, engineering based company.

When asked about how they organized their innovation activity the R\&D director of the company made an important distinction between application development ('machine' development) and technological development. Application development means solving concrete problems in connection with building the specific equipment for customers. This is carried out drawing on internal engineering competence as well as in interaction with suppliers and customers, and is, thus, an example of the DUI mode of (incremental) innovation. In addition professional R\&D firms (consultancy firms) domestically and abroad are used. Technology development means development of more general platform technologies, which represents the technological basic competence for carrying out application development. While the application development is only made in-house or in user-producer relationships, technological development takes place in cooperation with (technical) universities as applied research projects, and represents, thus, the STI mode of innovation but still based on synthetic knowledge.

Concerning cooperation with university this can take place on normal open conditions when it is a question of general technological platform development, but not with respect to how to apply this general technology in application development. Then results from 
research on technological development are applied in concrete, individual projects, which underpin the competitive advantage of the company.

In cooperation with universities on applied research projects geographical proximity matters most, and instead of always accessing the best competence globally found at places such as MIT, the company chooses to focus on the geographically closest available competence. Thus, they prioritize building up research cooperation with the regional university by among other things employing some professors in $20 \%$ positions in the company as a way of strengthening the competence at the university to be applied in collaborative research projects. In addition they take a central part in funding and using a regional, applied research organisation. The company called this form of carrying out applied research 'cooperation at the operational level', which, according to the company, is the right level of research collaboration for technological development. To achieve this, geographical proximity is of great importance. In addition the company cooperates with national and international top universities in research projects on technological development, which always involve company funded PhD's to secure a more long-term 'payback' for the company. In order to strengthen the relationship to the company they also make sure that one of the supervisors is coming from the company, which provides organizational as well as institutional proximity (BOSCHMA, 2005). ${ }^{\mathrm{iii}}$

This example illustrates how such a 'bridging device' can work to solve the problem of a too wide cognitive distance, and, thus, achieve a combination of the two modes of innovation. In a learning region perspective this is important as it demonstrates that the 
picture of very limited upgrading potentials of firms and clusters in learning regions is not the whole story to be told. Furthermore, the example illustrates how 'second best' regional universities can be used and upgraded by large companies to become active partners in collaborative $\mathrm{R} \& \mathrm{D}$ projects in addition to the companies also using non-local, more internationally leading universities. This vitalizes and strengthens the viability of the learning region approach even in a globalizing knowledge economy.

\section{THEORETICAL DEVELOPMENTS IV: DISTRIBUTED KNOWLEDGE NETWORKS AND NON-LOCAL RELATIONS}

As a result of the growing complexity and diversity of contemporary knowledge creation and innovation processes, firms increasingly become parts of network organised innovation projects. This implies a growing need to acquire new knowledge to supplement their internal, core knowledge base(s) - either by attracting human capital possessing competences based on a different knowledge base or by acquiring new external knowledge base(s) by collaborating with external firms through $R \& D$ cooperation, outsourcing or offshoring of $\mathrm{R} \& \mathrm{D}$, and/or with research institutes or universities, which underline the importance of firms' absorptive capacity. The strategy of acquiring and integrating external knowledge base(s), therefore, implies that more and more a shift is taking place from firms' internal knowledge base to increasingly globally 'distributed knowledge network' ${ }^{\text {iv }}$ and 'open innovation' (CHESBROUGH, 2003). This is manifested by the increased importance of and attention to clusters, innovation systems (regional, national and sectoral), global production networks and value chains for firms' knowledge creation and innovation processes, demonstrating that the relevant 
knowledge base for many industries is not internal to the industry, but is distributed across a range of technologies, actors and industries' (SMITH, 2000, 19). The creation of regional innovation systems through increased cooperation with local universities and R\&D institutes, or through the establishment of technology transfer agencies, may provide access to knowledge and competence that supplements firms' locally derived competence (as was shown in the example above). This not only increases their collective innovative capacity, but may also serve to counteract technological 'lock-in' (the inability to deviate from an established but outdated technological trajectory) within regional clusters of firms.

Thus, there seems to be a generic and global trend towards integration and collaboration in firms' knowledge creation and innovation processes. The development towards more and more distributed knowledge networks can, for example, be traced in several biotechnology clusters over the last 10-15 years. In fact, due to the strong growth of potential biotechnology applications, particularly in life science, it has been increasingly hard for firms as well as regions to host all necessary competences within its boundaries. This has resulted in a local node, global network geography of the life-science industry (COENEN, 2006; COENEN et al., 2006; GERTLER and LEVITTE, 2005).

Such local node-global network geography of knowledge creation, innovation and production is, however, not only found in typically analytical based industries applying a STI mode of innovation (such as biotech) but can also be identified in industries combining analytical and synthetic knowledge bases and STI and DUI modes of 
innovation. The wine industry could provide such an example (GUILIANI, 2005; GUILIANI and BELL, 2005).

These development tendencies, thus, challenge both the traditional endogenous approach and the 'local buzz-global pipeline' view on the importance of local vs. non-local knowledge resources (BATHELT et al., 2004). So far, all the way from Marshall's writing on industrial districts, it has been assumed that business interactions (from exploiting localization economies) and knowledge flows were co-occurring (and colocated) phenomena. Furthermore, it has been maintained that local interactions and collective learning processes, or what is sometimes called 'local buzz', largely take care of themselves by just 'being there', while building 'global pipelines' to knowledge providers located outside the local milieu requires institutional and infrastructure support, as one cannot expect that it occur spontaneously.

It is this idea of an almost automatic shaping of endogenous learning and innovation capacity by just being co-located in a cluster, which also lies behind Porter's understanding of how competitive advantage is created, conditioned by the four determinants of the diamond being in place (PORTER, 1990; 1998). Recently, observers have questioned if cluster learning is a pervasive and 'collective' process only conditioned by territorial agglomeration as such (ASHEIM, 1996; 2000). New research has shown empirically that there exists an uneven distribution of knowledge and selective inter-firm learning due to the heterogeneity of firms' competence bases, which cannot be 
fully compensated by regional universities or other parts of a region's 'collective absorptive capacity’ (GUILIANI and BELL, 2005).

Thus, it is an important question if more planned and systemic approaches are needed in a globalising knowledge economy in order for regional advantages to be deliberately constructed (ASHEIM et al., 2006; ASHEIM et al., 2011). This argument is grounded in the fact that the contemporary globalising knowledge economy - characterised by outsourcing/offshoring of both production and R\&D, open innovation, dominating TNCs, and intensified competition from developing economies of which China and India are the 'star' examples, - is becoming relatively more knowledge intensive, and explicit, codified knowledge consequently increasing in importance. Constructing regional advantage means turning comparative advantage into competitive advantage through an explicit policy push promoting a Chamberlinian monopolistic competition based on product differentiation creating unique products, an assumption which was fundamental also for Porter's cluster approach. While building on the lessons from the dynamic principle of the theory of competitive advantage (PORTER, 1990, 1998) as well as of the innovation systems approach (LUNDVALL, 2008) emphasizing that competitiveness can be influenced by innovation policies and supporting regulatory and institutional frameworks, the constructed advantage approach recognises the important interplay between industrial and institutional dynamics as well as calls for greater attention to multi-level governance. What is especially highlighted is the role of a proactive public-private partnership and impact of the public sector and public policy support by acknowledging to a greater extent the importance of institutional complementarities in knowledge economies. This 
approach represents an improved understanding of key regional development challenges as well as a better anticipation and response to the problems by addressing system failures or lack of connectivity in regional innovation systems (ASHEIM et al., 2011).

This is, however, as argued in the article, not limited to activities based on an analytical knowledge base but also include activities based on synthetic and symbolic knowledge bases combining the STI and DUI modes of innovation. Simply leaving the question of how constructed advantage is attained just to the 'territory' in the Marshallian way, when tacit knowledge was most important, or to the Porterian primacy of (market) rivalry, is probably not enough, even if tacit knowledge and incremental innovations - especially in synthetic and symbolic knowledge bases - still remains of strategic importance for firms' and regions' competitiveness. New theoretical developments providing a much more nuanced view of how to understand knowledge, learning and innovation (ASHEIM et al., 2011; LORENZ and LUNDVALL, 2006), as well as ongoing research showing that development of innovation systems and quality of governance matters most with regard to economic performance both for developed and developing economies (FAGERBERG and SHROLEC, 2008) imply a changing role of learning regions. This can represent a useful context for implementing a pro-active, public-private partnership based, broad innovation policy aiming at constructing advantage at the regional level, making the learning region approach a more realistic policy alternative for regions globally.

\section{CONCLUSION: THE FUTURE ROLE OF LEARNING REGIONS IN A GLOBALISING KNOWLEDGE ECONOMY}


After years of influential research on the importance of territorial agglomerations for economic growth there is a need for an 'unpacking' strategy to disclose and reveal the contingencies, particularities and specificities of the various contexts and environments where knowledge creation and innovation take place in order to obtain a better understanding of factors enabling or impeding these processes. The need for such a theoretical re-examination is not the least when analysing the changing and future roles of learning regions in the globalising knowledge economy. In this article we have highlighted four different theoretical developments, which we think are of importance to understand the changing and future role of learning regions. First, we pointed at how the perspectives of the learning economy as well as development coalitions moved the concept of learning regions from the often specific context of Third Italian industrial districts to become a more general, applicable regional development strategy, as is illustrated by the use of this way of understanding learning regions in the Regional Innovation Strategy pilot actions of the EU commission. Secondly, the introduction of the DUI mode of innovation showed that the typical interactive, incremental way of learning and innovating in a learning region represented a distinct mode of innovation, which linked with the potentials represented by developmental learning mean that upgrading possibilities exist to embark on a high road development strategy. Thirdly, the inclusion in the STI mode of innovation of knowledge creation based on synthetic and symbolic knowledge bases (and not only on the analytical knowledge base), as well as the emphasis of the role developmental learning can play in a DUI mode of innovation, represent 'bridging mechanism'. This will reduce the cognitive distance between the two modes of innovation, andcan, thus, provide the basis for combining the two modes of 
innovation. And fourthly, the need for accessing additional knowledge outside the firm and cluster in distributed knowledge networks makes the building of RIS even more important, where a learning region approach can represent a realistic alternative for implementing a public-private partnership based, broad innovation policy.

In such a process learning regions can play an important role in the formation of RIS broadly defined which constitute a necessary condition for achieving development in as well as of regions. To link a DUI operating RIS with a STI operating, narrowly defined RIS, either in the same region or on an inter-regional basis, can in many ways be seen as representing the sufficient condition for securing a sustainable economic and social development in a globalising knowledge economy. To achieve this, the cognitive distance of key actors in the broadly and narrowly defined innovation systems should not be too wide, and the connectivity within and between the systems high. At the regional level the learning region approach can play a specifically important role providing the context for the formation of a RIS broadly defined securing the organizational framework for a DUI mode of innovation where developmental learning is taking place. An example of a regional innovation policy initiative reflecting these ideas is the Norwegian VRI program (Policies for regional R\&D and Innovation) funded by the Norwegian Research Council. The program builds on constellations of Triple-Helix actors which are referred to as 'regional development coalitions' and aims of combining DUI and STI modes of innovation on the regional level. This program represents with the exception of the Regional Innovation Strategy pilot actions of the EU commission (BELLINI and LANDABASO, 2007) one of the very few attempts of promoting and 
implemented a broad based innovation policy at the regional level, and is, thus, a rather unique innovation policy program in an international context.

The new theoretical developments, presented in the article, transcending the dichotomised view of knowledge, learning and innovation into a more nuanced understanding of types of knowledge, forms of learning and modes of innovation represent important 'bridging mechanism' to reduce the cognitive distance and increase the connectivity in the comprehensive regional innovation system. In this process the new way of understanding the changing role of learning regions points to a potential important future role of the approach in promoting development in developed as well as developing regions in the globalising knowledge economy. 


\section{REFERENCES}

AMIN, A. and THRIFT, N. (1995) Territoriality in the global political economy, Nordisk Samhällsgeografisk Tidskrift 20, 3-16.

ARUNDEL, A., LORENZ, E., LUNDVALL, B. Å., and VALEYRE, A. (2007) Europe's economies learn: a comparison of work organization and innovation modes for the EU-15, Industrial and Corporate Change 16(6), 1175-1210.

ASHEIM, B. T. (1996) Industrial districts as "learning regions": A condition for prosperity? European Planning Studies 4(4), 379-400.

ASHEIM, B. T. (2000) Industrial districts: The contributions of Marshall and beyond, In Clark, G., Feldman, M. and Gertler, M. (Eds), The Oxford Handbook of Economic Geography, pp. 413-431. Oxford University Press, Oxford.

ASHEIM, B. T. (2001) Learning regions as development coalitions: Partnership as governance in European workfare states? Concepts and Transformation. International Journal of Action Research and Organizational Renewal 6(1), 73-101.

ASHEIM, B. T. and COENEN, L. (2005) Knowledge Bases and Regional Innovation Systems: Comparing Nordic Clusters, Research Policy 34(8), 1173-1190.

ASEHIM, B. T. and GERTLER, M. S. (2005) The Geography of Innovation: Regional Innovation Systems, In FAGERBERG, J., MOWERY, D. and NELSON, R. (Eds) The Oxford Handbook of Innovation, pp. 291-317. Oxford University Press, Oxford.

ASHEIM, B. T. and HANSEN, H. K. (2009) Knowledge bases, talents and contexts. On the usefulness of the creative class approach in Sweden, Economic Geography 85(4), $425-442$.

http://mc.manuscriptcentral.com/cres Email: regional.studies@fm.ru.nl 
ASHEIM, B. T., BOSCHMA, R. and COOKE, P. (2011) Constructing Regional Advantage, Regional Studies 44 (forthcoming).

ASHEIM, B. T., ISAKSEN, A., NAUWELAERS, C., AND TÖDTLING, F.(Eds) (2003) Regional Innovation Policy for Small-Medium Enterprises. Edward Elgar, Cheltenham.

ASHEIM, B. T., COOKE, P., ANNERSTEDT, J., BLAZEK, J., BOSCHMA, R., BRZICA, D., DAHLSTRAND LINDHOLM, A., DEL CASTILLO HERMOSA, J., LAREDO, P., MOULA, M. and PICCALUGA, A. (2006) Constructing regional advantage. Principles, perspectives, policies, Final report, EUROPEAN COMMISSION, DG Research, Brussels.

ASHEIM, B. T., COENEN, L., MOODYSSON, J., AND VANG, J. (2007) Constructing knowledge-based regional advantage: Implications for regional innovation policy, International Journal of Entrepreneurship and Innovation Management 7 (2/3/4/5), $140-155$.

BATHELT, H., MAlMBERG, A., MASKELL, P. (2004) Clusters and Knowledge: Local Buzz, Global Pipelines and the Process of Knowledge Creation, Progress in Human Geography 28 (1), 31-56.

BECATTINI, G. (1990) The Marshallian industrial district as a socio-economic notion, in PYKE, F., BECATTINI, G. and SENGENBERGER, W. (Eds) Industrial districts and inter-firm cooperation in Italy, pp. 37-51 International Institute for Labour Studies (ILO), Geneva. 
BELLINI, N. and LANDABASO, M. (2007) Learning about innovation in Europe's regional policy, in RUTTEN, R. and BOEKEMA, F. (Eds) The Learning Region. Foundations, State of the Art, Future, pp. 231-251 Edward Elgar, Cheltenham.

BERG JENSEN, M., JOHNSON, B., LORENZ, E. AND LUNDVALL, B. Å. (2007) Forms of knowledge and modes of innovation. Research Policy 36, 680-693.

BOSCHMA, R. (2005) Proximity and innovation: A critical assessment. Regional Studies 39, 61-74.

CHESBROUGH, H. (2003) Open Innovation, Boston, Harvard Business School Press, HARVARD, Boston, MA.

COENEN L. (2006) Faraway, so close! The changing geographies of regional innovation, Meddelanden från Lunds universitets geografiska institution, Avhandlingar CLXVIII, Lund.

COENEN, L., MOODYSSON, J., RYAN, C., ASHEIM, B.T. and PHILLIPS, P. (2006) Comparing a pharmaceutical and an agro-food bioregion: on the importance of knowledge bases for socio-spatial patterns of innovation Industry and Innovation $13,4,393-414$.

COHEN, W. M. and LEVENTHAL, D. A. (1990) Absorptive Capacity: A New Perspective on Learning and Innovation, Administrative Science Quarterly, 35(1), $128-152$.

COOKE, P. (2007) Regional innovation systems, asymmetric knowledge and the legacies of learning, in RUTTEN, R. and BOEKEMA, R. (Eds) The Learning Region. Foundations, State of the Art, Future,pp. 184-205. Edward Elgar, Cheltenham. 
EBENSBERGER, B. AND HERSTAD, S. (forthcoming) Product innovation and the complementarities of external interfaces, European Management Review.

ELLSTRÖM, P. E. (1997) The many meanings of occupational competence and qualification, Training, 266-273.

ENNALS, R. and GUSTAVSEN, B. (1999) Work organisation and Europe as a development coalition. John Benjamin's Publishing Company, AmsterdamPhiladelphia.

FAGERBERG, J. and M. SRHOLEC (2008) National innovation systems, capabilities and economic development. Research Policy 37(9), 1417-1435.

FAY, C. and BIRKENSHAW, J. (2005) External sources of knowledge, governance mode and R\&D performance, Journal of Management 31(4), 597-621

FLORIDA, R. (1995) Towards the learning region. Futures 27(5), 527-536.

GERTLER, M. (2008) Buzz without being there? Communities of practice in context, in AMIN, A. and ROBERTS, J. (Eds) Community, Economic Creativity and Organization, pp. 203-226. Oxford University Press, Oxford.

GERTLER, M. and LEVITTE, Y. (2005) Local Nodes in Global Networks: The Geography of Knowledge Flows in Biotechnology Innovation, Industry and Innovation 13, 487-507.

GIULIANI, E. (2005) The structure of cluster knowledge networks: Uneven and selective, not pervasive and collective, DRUID Working Paper 2005-11.

GIULIANI, E. and BELL, M. (2005) The Micro-determinants of Meso-level Learning and Innovation: Evidence from a Chilean Wine Cluster, Research Policy 34 (1), 47 68. 
HERSTAD, S. J, BLOCH, C., EBERSBERGER, B. and van den VELDE, E (2008) Open innovation and globalisaton: Theory, evidence and implications. Report, Vision Eranet.

JACOBIDES, M. and BILLINGER, S. (2006) Designing the boundaries of the firm: From "make, buy or ally" to the Dynamic Benefits of Vertical Architecture, Organization Science 17(2), 249-261.

JOHNSON, B., LORENZ, E. AND LUNDVALL, B. Å. (2002) Why All This Fuss About Codified and Tacit Knowledge? Industrial and Corporate Change 11, 245-62.

KOGUT, B. and ZANDER, U. (1996) What firms do? Coordination, identity and learning, Organization Science 7(5), 502-518.

LAESTADIUS, S. (1998) Technology Level, Knowledge Formation and Industrial Competence in Paper Manufacturing, In G. ELIASSON and GREEN, C. (Eds) The Micro Foundations of Economic Growth, pp. 212-226. The University of Michigan Press, Ann Arbour.

LAESTADIUS, S. (2000) Biotechnology and the potential for a radical shift of technology in forest industry, Technology Analysis \& Strategic Management 12, 193 212.

LAESTADIUS, S. (2007) Vinnväxtprogrammets teoretiska fundament, In LAESTADIUS, S. et al. (Eds), Regional växtkraft i en global ekonomi. Det svenska Vinnväxtprogrammet. Stockholm, pp. 27-56. Santerus Academic Press, Stockholm.

LAURSEN, K. and SALTER, A. (2004) Searching high and low: What types of firms use universities as sources of knowledge? Research Policy 33,1201-1215 
LORENZ, E. and LUNDVALL, B. Å. (Eds) (2006) How Europe's Economies Learn: Coordinating Competing Models. Oxford University Press, Oxford.

LORENZ, E. and VALEYRE, A. (2006) Organisational forms and innovative performance, In LORENZ, E. and Lundvall, B. Å. (Eds) How Europe's Economies Learn: Coordinating Competing Models, pp. 140-161. Oxford University Press, Oxford.

LUNDVALL, \B.Å. (Ed) (1992) National Systems of Innovation: Towards a Theory of Innovation and Interactive Learning. Pinter, London.

LUNDVALL, B.Å. (2008) National Innovation Systems - Analytical Concept and Development Tool, Industry \& Innovation 14(1), 95-119.

LUNDVALL, B.-Å. and JOHNSON, B. (1994) The learning economy, Journal of Industry Studies 1, 23-42.

LUNVALL, B.A. and BORRAS, S. (2005) Science, technology, innovation and knowledge policy, in FAGERBERG, J., MOWEREY, D. and NELSON, R. (Eds) The Oxford Handbook of Innovation, pp. 599-631 . Oxford University Press, Oxford.

MINISTRY of EMPLOYMENT and the ECONOMY (2008) Proposal for Finland's National Innovation Strategy. Helsinki.

MITCHIE, J. and SHEEHAN, M. (2003) Labour market deregulation, 'flexibility' and innovation, Cambridge Journal of Economics 27, 123-43.

MOODYSSON, J. (2007) Sites and modes of knowledge creation: On the spatial organisation of biotechnology innovation, $\mathrm{PhD}$-dissertation, Department of Social and Economic Geography. Lund University, Lund. 
MOODYSSON, J., COENEN, L. and ASHEIM, B. (2008) Explaining Spatial Patterns of Innovation: Analytical and Synthetic Modes of Knowledge Creation in the Medicon Valley Life Science Cluster, Environment and Planning A, 40, 1040-1056.

MORGAN, K. (1997) The learning region: institutions, innovation and regional renewal, Regional Studies 31, 491-504.

NOOTEBOOM, B. (2000) Learning and Innovation in Organizations and Economies, Oxford University Press, Oxford.

PIORE, M. and SABEL, C. (1984) The Second Industrial Divide: Possibilities for Prosperity. Basic Books, New York.

PORTER, M. (1990) The Competitive Advantage of Nations, Macmillan, London.

PORTER, M. (1998) Clusters and the new economics of competition, Harvard Business Review November-December, 77-90.

ROTHAERMEL, F., HITT, M. and JOBE, L. (2006) Balacing vertical integration and strategic outsourcing: Effects on product portfolio, product success and firm performance, Strategic Management Journal 27, 1033-1056.

RUTTEN, R. and BOEKEMA, F. (Eds) (2007) The Learning Region. Foundations, State of the Art, Future. Edward Elgar, Cheltenham.

SIMON, H. (1969) The Sciences of the Artificial, MIT Press, Cambridge.

SMITH, K. (2000) What is 'The Knowledge Economy'? Knowledge-intensive Industries and Distributed Knowledge Bases, Paper presented at the DRUID Summer Conference on 'The Learning Economy - Firms, Regions and Nation Specific Institutions', Aalborg, June 2000.

http://mc.manuscriptcentral.com/cres Email: regional.studies@fm.ru.nl 
STORPER, M. (1993) Regional 'worlds' of production, Regional Studies, 27, 433-455.

VAN DER BOSCH, F., VOLBERDA, H. and DE BOER, M. (1999) Coevolution of firm absorptive capacity and knowledge environment: Organisational forms and combinative capabilities, Organization Science 10(5), 551-568.

WOOLCOCK, M. (1998) Social capital and economic development: Toward a theoretical synthesis and policy framework, Theory and Society, 151-208.

ZAHRA, S. and GEORGE, G (2002) Absorptive capacity: A review, reconseptualisation and extention, Academy of Management Review 27(2), 1985-203. 


\section{TABLES:}

\begin{tabular}{|c|c|c|}
\hline Analytical (science based) & Synthetic (engineering based) & Symbolic (arts based) \\
\hline $\begin{array}{l}\text { Developing new knowledge } \\
\text { about natural systems by } \\
\text { applying scientific laws; know } \\
\text { why }\end{array}$ & $\begin{array}{l}\text { Applying or combining existing } \\
\text { knowledge in new ways; know how }\end{array}$ & $\begin{array}{l}\text { Creating meaning, desire, } \\
\text { aesthetic qualities, affect, } \\
\text { intangibles, symbols, images; } \\
\text { know who }\end{array}$ \\
\hline $\begin{array}{l}\text { Scientific knowledge, models, } \\
\text { deductive }\end{array}$ & $\begin{array}{l}\text { Problem-solving, custom production, } \\
\text { inductive }\end{array}$ & Creative process \\
\hline $\begin{array}{l}\text { Collaboration within and } \\
\text { between research units }\end{array}$ & $\begin{array}{l}\text { Interactive learning with customers } \\
\text { and suppliers }\end{array}$ & $\begin{array}{l}\text { Experimentation in studios and } \\
\text { project teams }\end{array}$ \\
\hline $\begin{array}{l}\text { Strong codified knowledge } \\
\text { content, highly abstract, } \\
\text { universal }\end{array}$ & $\begin{array}{l}\text { Partially codified knowledge, strong } \\
\text { tacit component, more context- } \\
\text { specific }\end{array}$ & $\begin{array}{l}\text { Importance of interpretation, } \\
\text { creativity, cultural knowledge, } \\
\text { sign values; implies strong } \\
\text { context specificity }\end{array}$ \\
\hline $\begin{array}{l}\text { Meaning relatively constant } \\
\text { between places }\end{array}$ & $\begin{array}{l}\text { Meaning varies substantially between } \\
\text { places }\end{array}$ & $\begin{array}{l}\text { Meaning highly variable } \\
\text { between place, class and gender }\end{array}$ \\
\hline Drug development & Mechanical engineering & $\begin{array}{l}\text { Cultural production, design, } \\
\text { brands }\end{array}$ \\
\hline
\end{tabular}

Table 1: Differentiated knowledge bases. A typology. (Source: ASHEIM and GERTLER, 2005; ASHEIM et al., 2007; GERTLER, 2008; ASHEIM and HANSEN, 2009). 


\section{ENDNOTES:}

${ }^{\mathrm{i}}$ GUILIANI (2005) and GUILIANI and BELL (2005) confusingly refer to 'level of competence' as 'knowledge base' instead of using the term 'competence base' to avoid misunderstandings.

ii I am indebted to Sverre J. Herstad, NIFU for very valuable input concerning the role of organisational forms when combining the DUI and STI mode of innovations.

iii In contrast to R\&D work geographical proximity is not important for the manufacturing of the many parts used in the final assembly of the equipment as there, at least in principle, should be no iteration in carrying out such operations.

iv A globally distributed knowledge network is 'a systemically coherent set of knowledges, maintained across an economically and/or socially integrated set of agents and institutions' (SMITH, 2000, p. 19). 